\title{
The Question of Racism:
}

\section{How to Understand the Violent Attacks on Indian Students in}

\author{
Australia?
}

\author{
Michiel Baas \\ Asia Research Institute, National University of Singapore
}

\begin{abstract}
For the past ten years I have been involved in research on the topic of Indian student-migrants in Australia. What started in India in 2004 with the ostensibly simple questions why there was such a surge in Indian students' enrolments in Australia, turned into a study which had the question of migration at the heart of its investigation. Realising that the majority of Indian students based their decision for Australia on the relatively easy pathway the country offered towards permanent residency (PR), my research focused on understanding how such trajectories from student to migrant took shape. However, as I argued in Imagined Mobility (Anthem Press, 2010), while the propensity to apply for PR may be high, permanently residing in Australia was often not the objective. Instead many Indian students saw a PR as facilitating the start of a transnational existence. In this paper I will draw upon a vast collection of newspaper articles as well as ethnographic material collected over this period in order to produce a personalised account of how I, as an academic researcher, observed the discourse about Indian students in Australia 'migrate' from them being welcome international students and would-be migrants to unwelcome profiteers whose reason for being in Australia was highly contested. Questions I will focus on are: how did the violent attacks and subsequent debate about their racist nature impact the lives and trajectories of Indian student-migrants as starting transnationals; how did they themselves reflect on these attacks especially in relation to them being 'permanent residents'; and finally, what role do 'Indian students' continue to play in Australia’s skilled migration debate?
\end{abstract}

\section{Introduction}

On 15 March 2013 popular news website News.com.au announced that the Australian Immigration Department would soon be relaxing its 'work rules' for international students, allowing them to work in any job for up to four years after their graduation from an Australian university. The tone of the article was critical, as Julia Gillard, the Australian 
prime minister at the time, had vowed to 'crack down' on so-called 457 visas $^{1}$ and to put 'Aussies' first. The article continued by noting that in 2012 the number of former international students who were now working temporarily in Australia on so-called 485 skilled graduate visas ${ }^{2}$ had increased by $74 \%$ to 38,210 ('the same number of unemployed Australians aged 20 to 24, who were searching for their first job in January’). Allegedly Indian students made up $40 \%$ of this number. While the change was intended to make Australia a more attractive destination for high quality international students, Australian unions were dissatisfied with this explanation, as they claimed that recently graduated international students would 'snatch jobs from local graduates'. While changes in Australian migration rules and regulations are regularly reported on in Australian newspapers this particular news article stands out for various reasons. For one it shows that there has been an earlier discussion with regards to these particular visa categories and that the Prime Minister herself had made promises, making use of rather populist language ('crack down', 'putting Aussies first') to reduce the number of international students being granted such work visas. Indian students are mentioned specifically in the article as they appear to be overrepresented in the numbers. In addition to this the article makes no effort to explain the various visa categories mentioned $(457,485)$. The categories are assumed to be known to a broad audience and implied in this is the assumption that this audience is also aware of earlier discussions.

The above-mentioned article is part of a collection of over a thousand media reports (newspaper and magazine articles, blog posts, TV program transcripts and otherwise) that I collected over the period 2003-2015 on the broadly-defined topic of Indian/international students in Australia. It is a diverse collection that is mostly the result of making use of Google Alerts which informed me on an almost daily basis of news on the above-mentioned topic. In addition, various informants, one in particular being a former teacher with a small inner-city college in Melbourne catering mainly to South Asian students, would keep me upto-date with publications from local Indian community newspapers such as the South Asian

\footnotetext{
${ }^{1}$ This visa lets a skilled worker travel to Australia to work for up to four years if they are sponsored by an approved business. See: http://www.immi.gov.au/Visas/Pages/457.aspx

${ }^{2}$ This visa is for international students who have recently graduated from an Australian educational institution. It lets them work in Australia temporarily after having finished their studies. This visa has two streams: Graduate Work stream - for international students with an eligible qualification who graduate with skills and qualifications that relate to an occupation on a so-called Skilled Occupation List (SOL). This visa is granted for 18 months. Post-Study Work stream - for international students who graduate with a higher education degree from an Australian education provider, regardless of their field of study. This stream is only available to students who applied for, and were granted, their first student visa to Australia on or after 5 November 2011. This visa can be granted for up to four years from the date the visa is granted, depending on the visa applicant's qualification. See: http://www.immi.gov.au/Visas/Pages/485.aspx
} 
Times and Bharat Times. I will use this material to analyze how the discourse on Indian students could mutate over time from them being considered welcome newcomers and, perhaps, potential migrants, to a group of unwelcome 'others' who could be considered 'profiteers', making use of a migration system that had 'clearly' been put in place for other reasons than to facilitate an easy-route into Australia for under-qualified Indian 'migrants'. I argue that this narrative would subsequently percolate into the analysis of the alleged racistnature of the attacks on them in 2009, something that would eventually lead to the deeply disturbing conclusion that essentially these students had themselves to blame for these attacks. Although I have provided a detailed analysis of this material before in a publication that examines the impact Indian student-migration (and subsequent attacks) has had on the city of Melbourne (Baas 2014), in this paper I will offer a more personalized account in which I will also reflect on my own observations of and contributions to the 'debate'. While 'media panic' - providing a shorthand for describing the reactions from both Indian and Australian media has often been held to blame for the way the attacks were interpreted (as 'racist') and their role in 'demonizing' Indian students (leading up to a 'rationale' and perhaps even 'impetus' for the attacks) this paper will argue that the evocation of a 'media panic' also aids towards deflecting our attention from the bigger underlying and more structural issues that contributed to the situation whereby Indian students became victims of violent, racist attacks.

The point of this paper is two-fold: on the one hand it aims to examine how a particular narrative on Indian students could be constructed in which they were increasingly depicted in a negative way; on the other hand, it wishes to shed light on the position Indian students take up in the wider debate on skilled migration, multiculturalism and the ongoing commercialization of higher education in Australia. Indian students continue to play a central role in this debate as India remains one of the most important source countries (besides China) for future international students.

International education is one of Australia's key service export industries and many of the country's universities rely heavily on money from international students. However, in the analysis of the 'attacks' so far, little attention has been paid to how the debate about Indian students in Australia could unfold in the way it did. Why was there such a fierce debate over whether or not these attacks were racist? Why did so many of the media reports that came out during the period of 2008-2010 make reference to, for instance, the living conditions of Indian students (staying in low-rent far-off and thus 'more dangerous' suburbs), their part- 
time jobs (working evening and night shifts and thus traveling home late at night to these very same suburbs), and their enrolment in low-ranking, often only recently founded colleges, of which the quality was questionable at best, and which were generally referred to as 'PR factories'? While this paper acknowledges the considerable advances that have been made in scholarly research on racism, especially in terms of the way racism gets understood, interpreted and 'denied (e.g. Essed 1991; Van Dijk 1992; Dunn \& Nelson 2011), the paper steers clear of further theoretical engagement in order to create the necessary space to properly understand how the discussion about the violent, racist attacks on Indian students could develop the way it did. The paper will follow a largely chronological order, starting with 2003 when I first learned of the rapidly growing number of Indian students going to Australia, and ending in the present (2015), 'five years after the attacks'.

\section{Student/Migration Plans and the Indian Middle Class}

In 2003, I conducted fieldwork in Bangalore (now Bengaluru) in order to investigate how IT professionals employed in transnationally operating companies, such as Infosys, IBM and Oracle, negotiate the transnational character of their professions with living ostensibly 'local' lives. One evening I sat down for dinner with Sanjay and Gauri, both working for I-Flex Solutions at the time, an IT company providing tech-solutions to the banking and finance industry. While talking about their careers they mentioned that they were both saving up to do their Masters - potentially MBAs - abroad. They had considered various countries and although their preference was for the US they realized that getting a student visa might be an issue as they had friends who had been denied one, although they had already secured enrolment in an American university. Australia and Canada were countries they were now considering and they had made careful calculations of how much money they would need to finance their study-abroad plans. One of the options they were contemplating was taking out a student loan, something local banks were ethusiastically marketing at the time. It was not a topic that was in any way central to my research at the time but it kept susurrating in the background and would regularly return as something young Indian professionals were contemplating - the idea of pursuing studies overseas. Gradually I started noticing how it was also something Indian newspapers were frequently reporting on, with entire pages dedicated to making the best possible choice. Australia was strikingly present in such reports and regular 'education fests' and 'university road-shows' were announced where students could meet the staff of various Australian universities to make the best possible choice. From 
advertisements and (sponsored) newspaper specials it also became clear that part of the attraction for Australia was that it might facilitate a relatively easy route into an Australian permanent residency (PR). Realizing that Australia was hardly a traditional migration destination for middle class Indians, I started wondering about the reasons and motivations for wanting to study in and/or migrate to Australia. The few casual conversations I had with Indian students who were contemplating going to Australia at the time had already revealed that, indeed, the choice for a particular course was highly influenced by the possibility of applying for Australian PR. As such, I had become curious: how does one actually navigate such a route towards PR when it means having to juggle the dual role of international student and (future) migrant at the same time? And how does one deal with changes in migration rules and regulations along the way? Because one thing was already clear in 2003: neither the Australian government, nor its educational institutions cheerfully marketing its campuses and programs in Indian newspapers, gave any guarantees that one would actually be eligible for PR at the end of one's trajectory. In fact, as I would later find out, the law specifically barrred universities to market, and thus offer, anything but education. It was this dilemma that I was immediately confronted with when I conducted my first series of interviews with Indian students at the beginning of my fieldwork period in Melbourne in 2005.

\section{Fieldwork among Indian Student-Migrants}

In 2005, when I conducted most of my initial fieldwork in Melbourne, there were roughly 345,000 international students in Australia. ${ }^{3}$ About half of these were enrolled in so-called Higher Education, meaning universities and colleges. A limited but rapidly growing number (about fifty thousand) was enrolled in VET (Vocational Education and Training) courses and a slightly higher number (about sixty-five thousand) in so-called ELICOS or English Language Intensive Courses for Overseas Students. Indian students were primarily enrolled in Higher Education at the time. In total there were about 27,500 of them in Australia, with about 22,500 enrolled in courses at universities and colleges and about 3,500 in VET programs. Initially my fieldwork focused mainly on two groups of Indian students. The first group consisted mainly of Indian students at Monash University, one of Australia's higher ranked universities and part of the so-called G8 (or Group of Eight universities). Many of these students were members of a student organization called Yuva, based at Monash University’s Caulfield Campus. The other group were all loosely tied to an Indian cricket

\footnotetext{
${ }^{3}$ Data generated by making use of the on the pivot tables provided by the website of Australian Education International: https://aei.gov.au (Checked 14 April 2014).
} 
club and were enrolled in courses at RMIT University. Although both Monash and RMIT are respectable universities with solid reputations in teaching and research what I soon began to understand was that many Indian students I encountered had started questioning the choice they had made for a particular university. In fact, many were considering changing course providers as soon as (legally) possible. Various factors played a role in this. For one, there were students who were disappointed with the quality of education received, something that was (at least partly) influenced by the course fees they were paying and student loans they had taken out to finance this. Directly related to this was the idea of a PR which would make it possible to pay off these loans in Australian dollars after graduation. In addition to this, the constant discussions among students about PR had also raised awareness of how one could also be obtained by studying at a lower ranking and thus 'cheaper' college.

I was sitting on the couch in a home rented by a group of Indian students in the suburb of Glen Huntly one evening when a new student arrived fresh off the plane. Like most of the other students in the house he was to join Swinburne University, a mid-ranking university. The idea was that he would sleep on the couch for the next couple of days, until he had found his footing and a more permanent place to stay. Having barely sat down he was immediately bombarded with questions about why he had enrolled himself in a one and a half year computer science course at Swinburne. Wasn't he aware that he needed to study at least two years in Australia in order to qualify for PR? And wasn't he aware that 'computer science' would not generate enough points on the 'points test' that Australia used to assess whether a migrant would be able to make a positive contribution to the country’s perceived skills gap? Still dazed from the flight and the cold weather he had experienced outside, he sheepishly dodged some of the more pressing questions from the others in the room. PR was not that important to him, he uttered in defence, he had come to Australia for studies only. But his new friends were not convinced. One student had recently 'moved' from an IT course with Monash University to ‘accounting' with Central Queensland University (CQU), a university ranked at the bottom and offering course fees about half of that of Monash. The university was not great, he claimed while sipping from his chai, but at least it would get him PR which would allow him to pay back the student loan he had taken out and which was now resting on the troubled backs of his parents back home in Trivandrum.

Changing courses was a regularly returning topic throughout my fieldwork. While most students I met were ‘serious’ about their studies, the combination of having taken out large 
student-loans and the realization that it might be hard to repay these loans back in India put extra pressure on the idea of 'getting a PR'. As it was argued, at least 'then' one would be able to stay on in Australia and repay these loans. Of the 130 students I collected data on during the period of 2005-6, 58 indicated that the opportunity to apply for PR at the end of their studies was the prime reason for choosing Australia as a study-abroad destination; 32 revealed that they had already obtained a PR or had lodged their applications and were awaiting the outcome; 26 said that they were considering applying for PR; and finally only 14 voiced no interest in PR whatsoever. Yet the discussion I had with these students was not always as straightforward as these numbers imply. As the scene depicted above also shows, PR wasn't always directly on a students' mind before coming to Australia. It is this kind of murkiness in migration decisions that does not let itself to be easily captured by statistical data. In relation to this I would often wonder: what does PR mean to these students? For many PR wasn't necessarily about permanently settling in Australia. In pragmatic terms, PR would simply allow a student to repay a student loan and/or to make a return on investment. Yet, when talking about the future and the role Australia would potentially continue to play in this, students would explain that PR and eventual full citizenship would help them live what could be described as transnational lifestyles. As such, it was believed that PR would help remove the shackles of their Indian passports, which were perceived to be holding them back and forcing them to go through lengthy, confusing and expensive visa procedures whenever they wanted to go abroad. These narratives were laced with what would be described as typical middle class expectations of life in India and abroad. Many had friends and/or (often far-off) family members ('cousins') residing abroad. They had grown up with stories of life abroad, stories which were often readily contrasted with life back home, and which meandered around ostensibly romanticized notions of life in western countries. Bollywood was never far away in such descriptions: the pristine air quality of the mountains of Switzerland, the clean and spacious streets of Canada, the safety for women to take a train late at night in London, and more in general: the glamour of big city life in the West with all its opportunities to propel one's career. It had contributed to an impression/image of the 'abroad' that could be thought of as a sketch, a piecemeal impression, one that did not run very deep and was certainly not based on extensive research. Australia, for that matter, had really been 'that country' where you had kangaroos and koalas, no? At most, informants would be familiar with the image of the Melbourne Cricket Ground. Some had heard of boomerangs and 'how they had murdered all these aboriginals'. On one occasion I remember asking a student from Hyderabad what images of Australia he recalled from his childhood. 
He described how he had had a poster of a Baha'i temple in Sydney above his bed. He had always wanted to see it, he said. Not familiar with any such temple in Sydney it took me a while to realize that he was referring to the Sydney Opera House which bears some resemblance to the Lotus Temple in Delhi, the latter a building whose iconic shape Indians are generally well-familiar with.

Why recall such impressions, sketchy as they may be? Because they signal a dilemma which in the wider discussion about Indian students in Australia, their migration intentions, the choices they would eventually overwhelmingly make for low-ranking and mainly newly founded colleges, often gets disregarded simply because it doesn't allow itself to be easily captured in statistics. The image of the archetypical 'Indian student' in Australia which would come to dominate public portrayal and perception was devoid of the kind of murkiness and ambivalence which characterized the personal histories and narratives that I scribbled down in my notebook. How did this image develop over time?

\section{The Migration-Education Entanglement}

Throughout my fieldwork I was often confronted with the question why I was interested in the topic of Indian students in Australia, especially by those employed in the 'education industry', as Australia would generally refer to the business of offering education to international students. Sure, they were a growing presence in Australian universities, but weren't the Chinese far more dominating? When I explained that I was primarily interested in their dual role as students and migrants this was often met with an uninterested shrug: it was clearly not perceived as a problem. A conference that I attended during the latter part of my fieldwork illustrates how the issue was dealt with by those belonging to the 'education industry’. At this conference, organized among others by IDP, Australia’s largest (not for profit) recruiter of international students, the manager of CQU's student services delivered a well-received presentation on how it recognized and dealt with international students' related issues (Australian Education International Conference, 'Global Imperatives - Local Realities', 8-11 October). ${ }^{4}$ Although my research showed that the industry was well aware of how 'migration driven' the market had become ${ }^{5}$ and that, for instance, CQU's Melbourne-based

\footnotetext{
${ }^{4}$ The presentation is available here: http://www.aiec.idp.com/pdf/Thu\%201210\%20Baker\%20\&\%20Hawkins.pdf (Visited: 15-11-13)

${ }^{5}$ Besides 130 Indian students I also interviewed a 100 other people who were all, one way or the other, connected to their lives. Besides members of the established Indian community this also included a significant number of lecturers, student councilors, migration agents and others involved in the 'education industry', as Australia likes to refer to it.
} 
campus attracted mainly Indian students who were studying in courses that carefully matched migration criteria, the presentation made at the conference no mention of this. An informal talk with lecturers from several Melbourne-based universities afterwards revealed that they were surprised about this as well. Many of their international students were also Indian and questions and worries about migration were something they were confronted with on a daily basis, they said. Yet the general consensus seemed to be that providing information about this was not the responsibility of the education industry. In fact, except for two presentations delivered by Bob Birrell (Monash University) and Lesleyanne Hawthorne (University of Melbourne), both of whom showed that the market was clearly 'migration driven', the question of migration and how to deal with students' queries with regards to this were almost entirely absent. Informal conversations with conference attendees outside the conference venue confirmed a picture I had already developed based on interviews with education and migration agents as well as university staff dealing with the recruitment of international students. Migration was clearly not a topic anyone was keen to address. The reason I was given was straightforward: rules and regulations did not allow for universities to give advice on the matter as they were not allowed to offer anything but education. At the time, the ESOS (Education Services for Overseas Students) Act $^{6}$ was supposed to regulate the education and training sector's involvement with international students studying in Australia. In principle, the ESOS Act and associated legislation was meant to protect the interests of 'overseas' students by providing tuition and financial assurance. Closely connected to the ESOS Act was the National Code, the purpose of which was to provide nationally consistent standards for Commonwealth Register of Institutions and Courses for Overseas Students (CRICOS) registration ${ }^{7}$ and for the conduct of CRICOS-registered providers. At the time, the Code proved to be especially relevant when it came to understanding the thin line that education providers, education and immigration agents and others walked when dealing with and making money from international students. Under the bracket of 'marketing and student information', the Code stated that the provider was responsible for ensuring that marketing of its education and training services was carried out with integrity and accuracy. Particularly important was that the code also stressed that it must uphold the reputation of Australian

\footnotetext{
${ }^{6}$ Please note that this article does not deal with subsequent updates of the Act and Code and additional legislation implemented.

${ }^{7}$ The ESOS Act requires providers of courses to international students to register their institution and courses with DETYA (Department of Education, Training and Youth Affairs). The State Office of Higher Education (OHE) and the Education Minister approve registration before a code is allocated and the details are recorded on the CRICOS register. Providers and their agents must not promote a course to overseas students unless it is registered on CRICOS. See also:

http://cricos.dest.gov.au
} 
international education and training. 'Recruitment of overseas students must be conducted in an ethical and responsible manner.' However, it was clear that the ethical dimension of the migration-driven market was something that many involved were trying to grapple with. Discussing this with some lecturers of Victoria University who had recently gone on an 'education road-show' to India where they had visited a number of cities to recruit international students revealed that virtually every question they had been asked dealt with the potential migration outcome of their choice for a particular course. These same staff members admitted that they felt they had no choice to familiarize themselves with the migration rules and regulations in order to provide students with 'proper information', even though they were not supposed to.

\section{Student Protests and the 'PR Factory' in Operation}

When I finished fieldwork in early 2006 interest from mainstream media for the topic of Indian students in Australia was rapidly increasing. While this could partly be attributed to the high growth numbers making Indian students more visible in Australian cities, there also seemed to be an increase in incidents and issues which previously had only received attention from local Australian-Indian media. In particular, the focus would be on Indian taxi drivers, often students working part-time. Early on in 2006 it was found that there were many illegal taxi drivers (News.com.au 22-02-2006) and that there were no less than 3,000 'foreign students' driving illegally in Australia. ${ }^{8}$ Already, in 2005, it was clear that Indian taxi drivers met with regular violence and racism as the personal narratives that were published in the Indian Voice, a monthly community newspaper distributed free of charge via Indian grocery stores, showed (Oct.-Dec. 2005). In 2006, the murder of an Indian taxi driver in Melbourne sparked the first protest in which hundreds of Indian taxi drivers participated. It led the Melbourne based newspaper, The Age, to publish an article with the title: 'Why these drivers are upset' (13-08-2006). The protest ended after 'safety talks' (News.com.au 22-02-2006) and the taxi protesters were allowed to see the Victorian premier to share their concerns (The Age 21-08-2006). It was not the only protest Indian students were involved in that year. In the middle of March, students of the Melbourne campus of Central Queensland University organized a hunger strike after having en masse failed an accounting exam. The students claimed that they had been failed on purpose so that the university could make more money 'out of them' as they would have to take the same subject again the next semester. They were

\footnotetext{
${ }^{8}$ According to an investigation by Melbourne newspaper The Herald Sun. The article could no longer be retrieved but is also discussed here: http://www.drive.com.au/editorial/articledetail.aspx?ArticleID=33978\&vf=1
} 
of the opinion that they had not been taught the correct material in order to have been able to successfully pass their exam (ABC.net.au 16-03-2006; The Age 17-03-2006).

The year 2006 also saw the publication of my academic article on the migration ambitions of Indian students in Australia. Titled 'Students of Migration: Indian Overseas Students and the Questions of Permanent Residency', it appeared in the now defunct academic journal People and Place (14:1). The article built upon the argument that the propensity to apply for PR after graduation among Indian students was very high and highlights three case studies in order to show the varying degrees of influence migration ambitions have in the choice of university/course and the way it impacts day-to-day lives in Australia. In particular, the article explored the pressure of student loans, the perceived (low) quality of Australian education and the stress changing migration rules and regulations caused. It is also in this article that I make use of the term 'PR Factory' in order to highlight how students would often refer to those institutes that enrolled the highest number of Indian students as 'PR factories'. The term was readily picked up by newspapers and continues to be used in various forms such as migration and residency factory. ${ }^{9}$ While one of the points my paper intended to raise was that Indian students were often disappointed by the quality of education they received, even if PR was their primary motive, the story the papers picked up on was that most Indian students were actually migrants and were using these so-called 'PR factories' to gain an easy entry into Australia. As the Sydney Morning Herald summarized in a headline: 'Universities being used as immigration 'factories' (30-03-2006). The general tone in similar reports was one of 'exploitation' and an industry 'out of control'. It did not take very long for the international press to pick up on this as well, as an article in Times Higher Education (0505-2006) titled: 'Indians exploit Aussie skills gap’ shows. Various studies by Bob Birrell (2006) of Monash University as first author also generated considerable media attention. One of his studies, (People and Place, 14:1), concludes that a significant number of international students score lower on their IELTS (English language) exams when applying for PR than they did when they arrived in Australia as international students. Another study (People and Place, 15:1) reaches the conclusion that the number of international students commencing in cooking and hairdressing courses had nearly tripled over the 2004-2006 period. As only a minority of students actually ended up working in these occupations, the paper argues that the

\footnotetext{
${ }^{9}$ I am not making claims that I introduced the term 'PR factory', only that I can clearly trace the emergence of the term in newspaper articles after my paper was published. The term does not appear in media sources before that although frequently used by Indian students and those involved in the 'education industry'.
} 
main reason for enrolling in these courses is migration. The newspaper headlines at the time give an indication of how these studies were received. While The Australian (29-01-07) dryly reported that 'Overseas students fail in job language', The Age (29-01-07) was decidedly more dramatic with its headline that there is an 'English skills row over foreign students'. Furthermore, the Sydney Morning Herald (29-01-07) cautioned that '[u]nis [appear to be] open to students who fail English'. With the high enrolment numbers in hairdressing and cooking courses now public, and the conclusion that such courses are chosen for their potential to facilitate migration having sunk in, the Sydney Morning Herald summarized the concerns as follows: 'Skilled migration a rort: report' (26-03-07). Furthermore ABC.net.au spoke of 'loopholes' in the migration system (28-03-07). The Australian condensed the reactions to the report to 'Punish dodgy colleges' (28-03-07), while The Age actually called 'for student visa changes’ (28-03-07).

Meanwhile Central Queensland University found itself in somewhat of a predicament as it was forced to react to claims from The Sydney Morning Herald (22-03-07) that the university had registered more than 2000 plagiarism incidents at its Sydney campuses in the 2001-2006 period and that it had neglected to report students for breaching visa conditions, even after having repeatedly failed subjects. The article further highlights that the various CQU campuses specialized in courses that attract the highest number of points towards permanent residency and that students and academics had criticized the university for its low standards. In a reaction the university stated that 'All universities in Australia do exactly what we do, yet because we're the largest provider and we have downtown campuses, we're somehow seen as special'(Sydney Morning Herald 22-03-07). The remark is not only interesting for how casually it underlines the commonality of certain practices but how this came with a certain degree of visibility as well. Like CQU's city campuses in Melbourne and Sydney, many recently set-up colleges that catered exclusively to international students were located in Australia's inner cities. It was thus during this period that students studying at such colleges would become an increasingly visible phenomenon in Australian inner cities (see also Baas 2014).

During the second half of 2007 attention for so-called 'dodgy' colleges or 'PR factories' would increase in Australian papers. Gradually awareness increased that such smaller colleges often collaborated with much larger universities in various shapes and forms from 'satellite campus management' to offering specific 'degree programs'. The Sydney Morning 
Herald (23-08-07), for instance, reported on a 'plagiarism row' at the University of New England's satellite campus in Sydney, which was managed by a private partner, the Melbourne-based Melbourne Institute of Technology. An internal audit had found that of the 210 international students who had taken masters' courses in IT, a significant proportion of students' theses had been plagiarized. A cursory glance over some of the headlines of 2008 gives an alarming impression of the state of the Australian education industry; 'Cash-strapped foreign students “struggling to survive”' (ABC.net.au 06-02-08); 'Don’t treat them like cash cows' (Herald Sun 16-06-08); 'Overseas students of “new slave trade”’ (The Age 23-082008); 'Foreign students exploited’ (Sydney Morning Herald 11-09-08); 'Reigning in rogue colleges’; ““Sham” colleges operating with impunity’ (both in The Age 25-10-2008); 'Licence to fleece' (The Australian 27-10-08); 'Unlicensed agents luring students' (The Age 25-11-08); 'Overseas students exploited as cash cows’ (Sydney Morning Herald 17-12-08); 'Overseas students exploited’ (The Age 22-12-08).

This trend would continue into early 2009 with articles stating 'Migration fraud "rife” in overseas education’ (The Age 05-01-09); ‘Degrees still lure low-skill migrants’ (The Australian 19-01-09); 'Probe has watch on 20 colleges' (07-04-09); 'Pressure to rein in “corrupt” colleges’ (The Age 14-04-09); 'Dodgy colleges exploit foreign students’ (The Australian 16-04-09); and ‘Overseas students abused by bosses, landlords: union’ (Sydney Morning Herald 22-04-09). While these articles clearly indicate that not all was hunky-dory in the world of international education in Australia, they do not necessarily portend or explain the turn of events from May 2009 onwards. As we will see below, a number of violent and what could be construed as racially motivated attacks on Indian students garnered considerable press attention, not just fuelled by the heinousness of the crimes but also by the reaction of Indian students and their representatives. We will observe how this then culminated in a public debate in which Australian politicians, journalists and spokespersons for the Indian community actively and sometimes aggressively participated.

\section{Making of Racism and Violence}

It is usually the attack on Indian student Shravan Kumar Theerthala on 23 May 2009 which is mentioned as one of the first incidents that triggered the public outrage and the ensuing debate on violence and racism. The student in question was attending a birthday party in suburban Melbourne when party crashers attacked him with a screwdriver which left him 
battling for his life in the hospital. Already, in February 2009, a number of articles in The Age had highlighted the frequent (racially motivated) violence Indian students met with in Melbourne. According to an article published on 19-02-09 'Indians [were] told to keep a low profile.’ Robberies in Melbourne’s western suburbs had increased by 27 per cent and police estimated that a third of the victims were of Indian appearance. 'A special police group has been formed to combat the robberies amid fears that some are racially motivated and that Indian international students are soft targets because they carry iPods and laptops on trains late at night.' The police had advised Indian students to make sure they walked through a well-lit route, even it might take longer to reach home, and do not openly display signs of wealth, such as iPods and phones. Furthermore, they had been advised not to speak (loudly) in their native tongue. The police were further quoted: 'We do believe there are some [instances] where the victim is targeted because of Indian appearance.' Several publications mocked and criticized the advice the police had given - such as Sushi Das' response in The Age (24-02-09) titled 'Quiet, you down the back - you're not in India now'. However, what stands out is how contradictory the reports are. On the one hand, it is established that Indian students often travel late at night to far-off suburbs, having finished poorly paid part-time jobs yet, on the other hand, they are associated with carrying large sums of cash and other valuables such as expensive cell phones and iPods. More significantly, however, is that even late at night Indian students appear to be a clearly visible and recognizable group about whom 'others' (the articles do not reveal much more about the perpetrators than that they are 'young' and 'Australian') seem to have a wealth of information. As such, they appear to have become an undeniable element in the wider urban landscape of Melbourne, which is already characterized by multicultural diversity.

Numbers alone cannot quite explain why claims of racism - initially backed by the police and even accompanied with advice to reduce one’s apparent 'Indianness' in public space - would ultimately face harsh criticism in the Australian public debate about them. The headlines of May aptly reflect the tensions on various sides; 'Police visit India to brief students on staying safe' (The Age 13-05-09); Unis say they'll still rely on foreign students fees' (The Age 13-0509); 'High-risk training colleges face new audit' (The Age 21-05-09); 'International students target of racist attacks in Newcastle' (ABC.net.au 21-05-09). Sushi Das, herself a BritishAustralian writer of Indian origin, played a prominent role in the discussion. Raising awareness of the long history of (racially motivated) attacks and sometimes abysmal quality of education offered at some of the colleges, she described how countless foreign [Indian] 
students are 'duped, fleeced or blatantly misled by offshore education agents who, in many ways, are the linchpin of Australia's \$15 billion international education industry, the nation's third-largest export after coal and iron' (The Age 23-05-09). However, it is not just ‘foreign charlatans' who are involved in 'this bonanza industry', '[t]here are a worrying number of unscrupulous private college operators in Australia, or “crooks” as Immigration Minister Chris Evans described them this week, ready to swindle students the moment they land in the country' (The Age 23-05-09 A delegation of the Australian police had meanwhile travelled to India to discuss the attacks and, at the time, Deputy Prime Minister Gillard had made the announcement that she would scrutinise 'rogue colleges' (WAToday 26-05-09). It had, indeed, become clear that the attacks had become a concern for the Indian government as well, as 'India asks Australia to ensure security of its students' (Times of India 27-05-09) and 'Rudd steps in as tensions rise over attacks on students' (The Age 30-05-09) demonstrated.

On 31 May, a protest was held in inner-city Melbourne in which over four thousand Indian students participated (The Age 31-05-09). That same day, celebrated Bollywood actor Amitabh Bachchan announced that he was turning down an honorary doctorate awarded to him by an Australian university as a mark of protest (Times of India 31-05-09). To make matters worse, police intervention during the Melbourne protest faced harsh criticism for its alleged use of excessive force (SBS 01-06-09) - apparently having punched protesters (The Australian 01-06-09) - and the eighteen arrests made that day (Herald Sun 01-06-09).

\section{Denial of Racism and Shifting the Blame}

The month of June marked a turning point in the public focus and debate on the claims of racism and violence made by Indian students. Although the The Age (02-06-09) kicked off the month with a report on a 'Fresh attack: Indian student slashed in Frankston' (a suburb in Melbourne), it also published a highly critical opinion piece by Akash Arora, chief sub-editor for design magazine Wallpaper and based in London at the time, who criticized the way the media dealt with the topic. Having moved to Sydney as an international student in 2003 himself, he 'found racism lurking more in the immigrants' psyches than on the streets.' He seemed to suggest that Indian students had themselves to blame for not integrating into mainstream Australian society. The Sydney Morning Herald (02-06-09) quoted a Sydneybased cardiologist and community leader of Indian descent who claimed that the Indian media's coverage of the plight of Indian students in Australia has been 'irresponsible' and 
that this could even backfire on Indians who have lived in Australia for years. These 'Indian' [community members'] reactions reverberate in the larger discussion about the question which has erupted over the alleged racist nature of Australians in general. An opinion piece in The Herald Sun concluded loudly 'We're not racists' (03-06-09) yet a day later a piece in The Australian - 'Blind eye to racism' - basically argued the polar opposite. The ensuing debate was like watching a tennis match between strongly determined opponents who keep on smashing the ball across the net with equal fervour; 'Racism cry is the only weapon' (The Age 04-06-09); 'Ugly times, yes, but let’s not take the big stick to Victoria' (The Age 04-0609); ‘Attacks not racial, say long-time Indian groups’ (The Age 05-06-09); and so on.

While it is mainly Australian politicians and police officials who made a point of assuring 'India' that Australia is not a racist country and that the attacks can be explained in other terms, members of the established Indian community, on the other hand, focussed their attention on the Australian audience at home, explaining to them that they also did not think Australians were racists (or that the attacks were racially motivated). Important in both explanations is how the argument of Indian students being so-called 'soft targets' is emphasized. About the case of stab-victim, Indian student Baljinder Singh, for instance, Deputy Police Commissioner Keiran Walshe was quick to deny that racism had played a part in the attack. Instead there was a perception that Indians were a 'weak prey' to criminals (The Australian 09-06-09). Opinion pieces such as the one published in The Age (08-06-09) titled 'Indians an easy target for cowards lurking in shadows' do not just draw attention to the risk run by traveling home late at night but also make rather misguided efforts to nuance the notion of Australia as a dangerous/racist country: 'India’s angry response to recent attacks is understandable, even if it glosses over the fact that violence is far more a part of life there than it is here (The Age 08-06-09). An article in the Sydney Morning Herald (11-06-09) even went so far as to point out that 'Indians should learn to treat their lower castes better' before complaining about how Indian students were treated in Australia. A blog post by Andrew Bolt for The Herald Sun (03-06-09) started with the following: 'Amazing that India which perfected the caste system and is plagued by Hindu-Muslim bloodfests is telling us we're too prejudiced.' Bolt doubts that Australian students would be much safer if they had comparable jobs as Indian students, working late at night and taking nearly deserted trains back home afterwards. Moreover, he adds that: 'Many of their attackers are Africans, Islanders, and less often Asians who are newcomers themselves, beneficiaries of our eagerness to seem kind and tolerant.' The ethnicity other than White/Anglo-Saxon Australian is further emphasized in an 
article in the Sydney Morning Herald titled 'Brutal Truth about Attacks' (09-06-09) in which the author elaborated on how a recent attack in Harris Park in Sydney involved assailants of Middle Eastern appearance; footage apparently showed that most of the young men robbing and repeatedly attacking an Indian student 'do not appear to be white.' Although some of these opinion pieces reveal a disturbing kind of racism in itself, the Australian authorities declared in the second week of June that the attacks on students were not racial. 'Indians living in Australia are not the targets of racial hate crimes, despite violent attacks and underreporting of assaults, authorities say' (The Australian 09-06-09). That same day, however, there was a rally in Sydney against assaults involving Indians (The Age 09-06-09). It was reported that there might be 'Would-be vigilantes patrolling Melbourne train stations' (ABC.net.au 09-06-09); and that 'Retaliation fears grow as students watch their backs' (ABC.net.au 09-06-09). A day later, Victoria’s Chief Police Commissioner Simon Overland publicly admitted that some of the attacks were ‘clearly racist in motivation' (The Age 10-0609).

Throughout June 2009, the debate continued on whether or not the attacks were racist, what role other migrant groups played in the violence and in what way Indian students themselves were (partly) responsible for the violence/racism they face: 'Lifting the veil on our ingrained racism' (The Age 13-06-09); 'Street violence to blame, not racism' (The Age 14-06-09); ‘Acknowledge this racism’ (The Australian 20-06-09); ‘Australians struggling with multiculturalism' (The Herald Sun 24-06-09); and '85\% Australians feel racism exists in Australia' (Times of India 24-06-09). By July it became clear that the attacks were having an adverse effect on future enrolments from India, Australia's second largest source country for international students. A fresh delegation of officials was sent to India in order to 'rescue lucrative student industry’ (Sydney Morning Herald 01-07-09) and Australian politicians continued to discuss the safety of international students, even working on a 'policy to assist foreign students' in order to cope with issues of violence (Radio Australia 02/03-07-09). In the meantime, an increasing number of 'dodgy colleges' were being forced to close doors, the result of, as The Age phrases it, an 'audit blitz' (14-07-09). A college which closed shop overnight left 350 international students 'stranded' (The Age 17-07-09). Police were reported to have raided migration agents' offices (ABC.net.au 27-07-09) and greater regulation for migration agents was called for (ABC.net.au 28-07-09). Although fresh attacks on students were still regularly reported on, increasingly the focus was on the closing down of colleges and, in relation to this, on international students who were unable to finish their courses; 
declining international student numbers because of the damaged reputation; and the bruised relationship between India and Australia.

\section{A Return to the Present: Imagining Australia}

From 2010 onwards, Indian student enrolments in Australia declined rapidly. Besides the negative press over (violent/racist) attacks on students, the increasingly expensive Australian dollar was also a factor. From more than 120,000 by the end of 2009, the number dipped to just under 100,000 a year later, declining further to a little over 70,000 the subsequent year, and finally stabilizing around 55,000 by 2012, bringing the number back to what it was five years previously. Throughout 2010, new 'attacks’ continued to make headlines but gradually the reporting and discussions lessened and so did the focus on so-called 'dodgy colleges', many of which were forced to 'close shop' in the previous period. A particular concern in this period was how to repair the damaged relations between Australia and India, a country not only important as a source for international students but also as a trading partner of growing importance. A new envoy was sent to India to discuss the attacks with the then Minister of External Affairs, S.M. Krishna, (Hindustan Times 11-02-09) and, at the same time, the Australian government made concerted efforts to ‘decouple’ migration from education. Hairdressing was taken off the list of professions that generated the highest number of points upon application for PR (The Australian 17-05-10), a move which was reported on by The Age as 'Canberra slashes occupations on migration list' (17-05-10). But, as The Age warned, reflecting worried sentiments within the education industry: 'New migrant list will hit business' (18-05-10). It was now also becoming clear that the drop in Indian student numbers was affecting the local Victorian economy (The Age 06-06-10) and pessimists warned that it might take up to a decade before international student numbers would be as high again as they once were (The Age 08-06-10).

More recently, Indian student enrolments in Australian educational institutions seem to be on the rise again, however Australia continues to struggle with the entanglement of migration and education, especially knowing that close competitors such as New Zealand and Canada also offer their international students routes to permanent residency and/or ways of (temporarily) staying on after graduation. In India, the 'attacks' are not forgotten but have been gradually folded into a wider narrative of middle class anxieties about the potential dangers of studying/migrating/living abroad. When, during a recent project among 'new 
middle class professionals' in Delhi, I had a casual conversation with a coffee barista at Starbucks who was contemplating a master's degree in Australia, I was again reminded of the murkiness and ambivalence that is integral to such plans. Yes, he had indeed heard of the attacks, but he had also heard that campuses in the US could be dangerous, that Canada could be really cold and that there were neo-Nazis in Europe ('Germany, I think?'). Melbourne was 'best for liveability’ though, as he had recently learned from a ranking he had come across online.

While the internet already played an important role in students' decision-making projects in 2004, there was then still a considerable reliance on information from education/migration agents. Although a decade later these agents are still utilized to navigate complex studyvisa/education-loan trajectories, nowadays social media provides a much broader forum to quickly interact with others with similar plans and/or those who have already gone abroad. This particular coffee barista had received reassurances from a number of online friends who were already studying or (permanently) residing in Australia that Australians were generally 'kind people', the cities indeed clean, part-time jobs readily available and 'studies not too hard'. He quickly proposed these casual assessments to me with the expectation that I would also be able to contribute to the formation of a more cohesive opinion about this. Were his friends correct? What did I think? he wanted to know.

Bollywood's increased interest in Australia as a setting for its romantic dramas, the presence of Australian cricketers in India (employed in the Indian Premier League), the popularity of Australia as a holiday destination among a certain bracket of the Indian middle class, are all elements that contribute to an 'Indian' perception of Australia these days. Over time I have observed how the 'memory' of the Indian attacks of 2009 has lessened in importance in the way Australia is 'imagined' and 'fantasized about' in India. During my conversation with the earlier mentioned coffee barista the topic did not return as it was clearly not something he was worried about. Yet this does not mean that the attacks are no longer relevant. While the question of whether or not they were racially motivated has been a topic of public discussion and (subsequent) scholarly research alike, the case itself offers an important glimpse into the way a particularly discourse about 'newcomers' and their relation to/with space and place gets constructed over time. As such the analysis and observations presented above are not just revealing of how the growth of Indian students' presence in Australia was perceived over time, but also how various debates (commercialization of higher education, dependency of 
universities on international education, the idiosyncrasies of a skilled migration program) informed a broader understanding of the position and rights of this group within Australian society.

\section{Conclusion}

As mentioned in the introduction, the notion of a 'media panic' has often been evoked to explain the 'attacks' as well as the public outcry over the (alleged) racist character of these attacks. On the one hand it could be argued that over time the Australian media contributed to an ever-more negative image of Indian students; enrolling in dodgy colleges, working more than the allowed number of hours, being paid cash-in-hand, not integrating into local mores and simply invading space and place because of their sheer numbers. On the other hand there is the Indian media response to this, furiously reacting to the plight of Indian students in Australia, lambasting Australian authorities' denial of the 'clearly' racist nature of the attacks, calling for a strong reaction from the side of Indian authorities and hammering home the message that Australia is a dangerous and most of all racist country.

It cannot be denied that both Australian and Indian media took strong positions during the period in which the attacks were on-going. Nor cannot it be denied that in particular Australian media contributed to a predominantly negative construction of the archetypical Indian student whose presence in Australia could be read along the lines of him being a profiteer, making use of rules and regulations as he saw fit, and thus testing the elasticity of Australian hospitality. Furthermore it does seem that the Indian media had no qualms adding oil to flame by labelling Australia/Australians as racist and stirring up controversies between both countries, even resulting in tense diplomatic relations as well as demonstrations in Indian streets during which effigies of Australian politicians were burned.

Accepting this as 'explanation' brings with it a sense of everybody wins; it annuls claims of widespread Australia racism while still allowing for enough space to accept that some of the attacks were indeed racist. Furthermore it puts most of the blame squarely in the corner of the media with Indian media being overly eager to sensationalize and point fingers while the Australian media should have been more responsible in what it was contributing towards. Yet as mentioned in the introduction, doing so also has a tendency to deflect our attention from the more structural issues which contributed to the situation whereby Indian students could in 
fact become victims of violent, racist attacks. The growth in Indian student enrolments in Australia was by and large the product of the country opening up its skilled migration program, and thus the option to apply for PR, to international students. In effect the 'education industry', already in the process of rapid commercialization due to stringent budget cuts (see also Baas 2010), became one that started to facilitate migration. Already in 2005 this was a well-known and thoroughly debated 'fact' though it had yet to find its way into more mainstream Australian discussions on diversity and multiculturalism. The attacks on Indian students of 2009 should thus not only be read and discussed in terms of their (alleged) racist nature and in what way the 'media' was to blame but also in terms of the longer term factors which played a role in creating a potentially volatile situation. As such the 'attacks' draw our attention to the entanglement of skilled migration and international student programs and the way such an entanglement is embeddedness in a wider constellation of developments that are all, one way or the other, related to how the nation-state and what it is understood to stand for is interpreted and is everlastingly in a process of becoming. Now a 'thing of the past', as informants of mine who were students during my fieldwork in 20052006 period but who are now invariably Australian citizens would ostensibly assure me, the violent/racist attacks on Indian should most of all be remembered as a culmination of sorts; one which witnessed the confluence of a conundrumatic array of discussions ranging from the future and reputation of Australian education to the diversity, multiculturalism and the presence of 'others' in Australian cities. With Australia's strong reliance on skilled migrants and its universities' (over-)dependence on international students, it is unlikely that these discussions will not culminate in another 'unexpected' issue at some point in the future. Taking into account that many other countries with competitive skilled migration and enthusiastically marketed international education programs (e.g. Canada, New Zealand, Singapore, United Kingdom) the 'Indian student attacks' will remain an important point of reference for the years to come in order to understand the dangers and pitfalls of all too convenient entanglements.

\section{References}

Baas, M. 2006, 'Students of migration: Indian students and the question of permanent residency', People and Place vol. 11, no. 1, pp. 8-24.

_ 2010, Imagined Mobility. Migration and Transnationalism among Indian Students in Australia, Anthem Press, London \& New Delhi. 
2014, 'Victims or profiteers? Issues of migration, racism and violence among Indian students in Melbourne', Asia Pacific Review, vol. 55, no. 2, pp. 212-226.

Birrell, B. 2006, 'Implications of low English Standards among overseas students at Australian universities', People and Place vol. 14, no. 4, pp. 53-64.

— \& Rapson, V. 2005, Migration and the accounting profession in Australia. Report prepared for CPA Australia, Centre for Population and Urban Research, Monash University, Melbourne.

— Rapson, V. \& Smith, T.F. 2006, Australia's net gains from international skilled movements in 2004-05 and earlier years, Centre for Population and Urban Research, Monash University, Melbourne.

— Healy, E. \& Kinnaird, B. 2007, 'Cooks galore and hairdressers aplenty', People and Place vol. 15, no. 1, pp. 30-44.

Dunn, K. and Nelson, J.K. 2011, 'Challenging the public denial of racism for a deeper multiculturalism', Journal of Intercultural Studies, vol. 32, no.6, pp. 587-602. doi: http://dx.doi.org/10.1080/07256868.2011.618105

Essed, P. 1991, Understanding Everyday Racism: an Interdisciplinary Theory, Sage, Newbury Park, CA.

Hawthorne, L. 2005, “Picking winners”: The recent transformation of Australia's skilled migration policy', The International Migration Review, vol. 39, no. 3, pp. 663-669. doi: http://dx.doi.org/10.1111/j.1747-7379.2005.tb00284.x

— 2010, 'How valuable is “two-step migration”? Labour market outcomes for international student migrants to Australia', Asia-Pacific Migration Journal vol. 19, no. 1, pp. 5-36. doi: http://dx.doi.org/10.1177/011719681001900102

Van Dijk, T.A. 1992, 'Discourse and the denial of racism', Discourse \& Society, vol. 3, no. 1, pp. 87-118. doi: http://dx.doi.org/10.1177/0957926592003001005

\section{Media Reports}

\begin{tabular}{|c|c|}
\hline ABC.net.au & \\
\hline $16-03-06$ & 'Students threaten hunger strike after poor exam results’ \\
\hline 28-03-07 & 'Study highlights loophole in Aust skilled migration program' \\
\hline $06-02-08$ & ‘Cash-strapped foreign students “struggling to survive”’' \\
\hline 09-06-09 & 'Would-be vigilantes patrolling Melbourne train stations' \\
\hline 09-06-09 & 'Retaliation fears grow as students watch their backs’' \\
\hline $21-05-09$ & 'International students target of racist attacks in Newcastle' \\
\hline 27-07-09 & 'Police raid migration agent’s offices’' \\
\hline 28-07-09 & 'Call for greater regulation for migration agents' \\
\hline The Age & \\
\hline $17-03-06$ & 'More student protests planned' \\
\hline $13-08-06$ & 'Why these drivers are upset' \\
\hline 29-01-07 & 'English skills row over foreign students' \\
\hline 28-03-07 & 'Call for student visa changes’' \\
\hline 23-08-08 & 'Overseas students of "new slave trade”' \\
\hline $25-10-08$ & 'Reigning in rogue colleges’' \\
\hline $25-10-08$ & “"Sham” colleges operating with impunity' (both in The Age); \\
\hline $25-11-08$ & 'Unlicensed agents luring students’' \\
\hline 22-12-08 & 'Overseas students exploited’' \\
\hline 05-01-09 & 'Migration fraud “rife” in overseas education' \\
\hline 14-04-09 & 'Pressure to rein in “corrupt” colleges’ \\
\hline 19-02-09 & 'Indians told to keep a low profile’ \\
\hline
\end{tabular}


13-05-09 'Police visit India to brief students on staying safe'

13-05-09 'Unis say they'll still rely on foreign students' fees'

21-05-09 'High-risk training colleges face new audit'

23-05-09 'Our schools for scandal'

30-05-09 'Rudd steps in as tensions rise over attacks on students'

31-05-09 'Indian students march in protest against attacks'

02-06-09 'Fresh attack: Indian student slashed in Frankston'

04-06-09 'Racism cry is the only weapon'

04-06-09 'Ugly times, yes, but let's not take the big stick to Victoria'

05-06-09 'Attacks not racial, say long-time Indian groups'

08-06-09 'Indians an easy target for cowards lurking in shadows'

09-06-09 Anger at assaults: Indians rally in Sydney

10-06-09 'Foreign students could be forced to leave'

13-06-09 'Lifting the veil on our ingrained racism'

14-06-09 'Street violence to blame, not racism'

14-07-09 'Audit blitz hits “dodgy” colleges'

17-07-09 'College crash strands 350 foreign students'

17-05-10 'Canberra slashes occupations on migration list'

18-05-10 'New migrant list will hit business'

06-06-10 'Student drop hits economy'

08-06-10 'Decade to regain foreign students'

The Australian

29-01-07 'Overseas students fail in job language'

28-03-07 'Punish dodgy colleges'

27-10-08 'Licence to fleece'

19-01-09 'Degrees still lure low-skill migrants'

16-04-09 'Dodgy colleges exploit foreign students'

01-06-09 'Police “punched” Indian protesters'

04-06-09 'Blind eye to racism'

09-06-09 'Foreigners hide crimes due to visa fears'

09-06-09 'Indian attacks not racial - authorities'

20-06-09 'Acknowledge this racism'

17-05-10 'Hairdressers out as migrant skills list gets a trim'

The Herald Sun

16-06-08 'Don't treat them like cash cows.'

01-06-09 '18 arrests amid Indian protest over Melbourne race violence'

03-06-09 'Indian students leaving Australia in wake of racist attacks'

24-06-09 'Australians struggling with multiculturalism'

Hindustan Times

11-02-09 'Indian envoy to Australia apprises Krishna on attacks'

Indian Voice

Oct. 2005 'It's not easy being a taxi driver'

Nov. 2005 'It's not fun being a taxi driver. Racist remarks/abuses'

Dec. 2005 'Late Night Surcharge: Is it 20\% or ...?'

News.com.au

22-02-06 'Illegal workers driving cabs'

Radio Australia

02-07-09 'Australian politicians discuss safety of foreign students'

03-07-09 'Australia works on policy to assist foreign students'

Sydney Morning Herald 
30-03-06 'Universities being used as immigration factories'

29-01-07 'Unis open to students who fail English'

22-03-07 'All unis playing migrant game'

26-03-07 'Skilled migration a rort: report'

23-08-07 'Plagiarism row: student decries uni standards'

11-09-08 'Foreign students exploited'

17-12-08 'Overseas students exploited as cash cows'

22-04-09 'Overseas students abused by bosses, landlords: union’

02-06-09 'Indian students want concession cards'

11-06-09 'Indians should learn to treat their lower castes better' Sydney Morning Herald

09-06-09 'Brutal Truth about Attacks'

01-07-09 'India delegation to rescue lucrative student industry'

Times of India

27-05-09 'India asks Australia to ensure security of its students'

31-05-09 'Amitabh Bachchan turns down Australian doctorate as mark of protest'

24-06-09 '85\% Australians feel racism exist in Australia' 